Jurnal Pendidikan Matematika : Judika Education

Volume 2, Nomor 2, Juli-Desember 2019

e-ISSN : 2614-6088

p-ISSN : 2620-732X

DOI: https://doi.org/10.31539/judika.v2i2.858

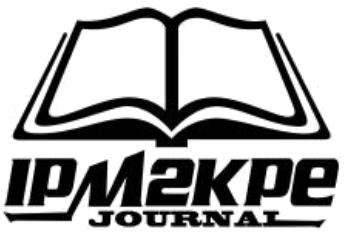

\title{
DESAIN PEMBELAJARAN MENGGUNAKAN TESSELLATION BERBASIS PENDEKATAN SAINTIFIK PADA MATERI TRANSLASI DAN REFLEKSI
}

\author{
Widiawati \\ STKIP Muhammadiyah Pagaralam \\ widiawati141@gmail.com
}

\begin{abstract}
ABSTRAK
Tujuan penelitian ini adalah untuk mengetahui peran tesselation pada materi translasi dan refleksi dalam mengembangkan komunikasi matematis siswa berdasarkan pendekatan saintifik. Metode penelitian menggunakan design research type validation study dengan melibatkan 30 siswa kelas VII SMP Negeri 9 Palembang. Proses penelitian menghasilkan learning trajectory yang memuat serangkaian proses pembelajaran dalam dua aktivitas yaitu saintifik pada materi translasi dan saintifik pada materi refleksi. Setiap aktivitas saintifik terdiri dari mengamati, menanya, menalar, mencoba, dan membentuk jejaring. Hasil penelitian menunjukkan dengan diberikannya materi pembelajaran melalui pendekatan saintifik, peran tesselations dapat membantu siswa untuk melakukan komunikasi matematis sehingga dapat mengidentifikasi materi translasi dan refleksi. Oleh karena itu, siswa dapat memahami konsep-konsep translasi dan refleksi serta menyelesaikan masalah-masalah yang berkaitan dengan materi tersebut. Simpulan, pembelajaran menggunakan tessellation dengan pendekatan saintifik efektif membantu siswa memahami konsep-konsep translasi dan refleksi, melalui kegiatan seperti mengamati, menanya, menalar, mencoba, dan membentuk jejaring
\end{abstract}

Kata Kunci: Komunikasi Matematis, Pendekatan Saintifik, Tessellation

\begin{abstract}
The purpose of this study was to determine the role of tesselation in translational and reflection material in developing students' mathematical communication based on a scientific approach. The research method uses design research type validation study involving 30 students of class VII SMP 9 Palembang. The research process produces learning trajectory which contains a series of learning processes in two activities, namely scientific on translational material and scientific on reflection material. Every scientific activity consists of observing, asking, reasoning, trying, and forming networks. The results of the study showed that by providing learning material through a scientific approach, the role of tesselations could help students to carry out mathematical communication so that they could identify translational and reflection material. Therefore, students can understand the concepts of translation and reflection and solve problems related to the material. In conclusion, learning using tessellation with a scientific
\end{abstract}


approach effectively helps students understand the concepts of translation and reflection. Through activities such as observing, asking, reasoning, trying, and forming networks

Keywords: Mathematical Communication, Scientific Approach, Tessellation

\section{PENDAHULUAN}

\begin{tabular}{lrr}
\multicolumn{2}{c}{ Translasi dan refleksi } \\
merupakan bagian dari pokok \\
bahasan geometri transformasi.
\end{tabular} Kershaw (2014) menyatakan bahwa transformasi adalah perpindahan dari bentuk geometri. Bentuk-bentuk geometri tersebut dapat berupa polapola dalam tessellation. Deger (2012a, 2012b) mendefinisikan bahwa tessellation sebagai pengaturan suatu bentuk yang menutupi bidang tanpa tumpang tindih atau meninggalkan celah. Desain-desain dari bentuk tesselation mempunyai nilai seni yang tinggi. Untuk membuatnya pun diperlukan pengetahuan-pengetahuan tentang konsep-konsep matematika yang diantaranya mengenai konsep translasi dan refleksi. Oleh karena itu, tesselation dapat digunakan dalam memahami konsep-konsep tersebut.

Fonseca \& Vale (2009) mengatakan bahwa pola (termasuk pola dalam tesselation) banyak memberikan peluang dalam belajar konsep matematika dan pengembangan proses matematika yang diantaranya seperti komunikasi matematika terutama dalam mempelajari translasi dan refleksi. Dengan adanya peluang tersebut menunjukkan bahwa materi itu begitu penting untuk dipelajari di matematika sekolah. Menurut Hollebrands (2003), ada tiga alasan penting untuk belajar translasi dan refleksi di matematika sekolah yakni menyediakan peluang untuk siswa berpikir mengenai konsep matematika yang penting (seperti fungsi, simetri), menyediakan suatu konteks yang mana siswa dapat melihat matematika sebagai mata pelajaran yang saling berhubungan, dan menyediakan peluang untuk siswa mulai melakukan aktivitas pemikiran tingkat tinggi menggunakan berbagai representasi. Berdasarkan alasan tersebut, siswa harus benar-benar memahami konsepkonsep translasi dan refleksi.

Guven (2012) mengungkapkan beberapa studi (Clements \& Burns; Edwards; Olson, Zenigami \& Okazaki; Rollick) yang menunjukkan bahwa siswa mengalami berbagai kesulitan dalam memahami konsep dan perbedaan dalam penyelesaian dan mengidentifikasi translasi dan refleksi. Selain itu, Tunnisa, Rizal \& Karniman (2018) menyatakan bahwa hasil belajar siswa rendah pada materi translasi dan refleksi karena tidak memahami prinsip-prinsip dari materi tersebut. Dengan demikian, guru sangat berperan dalam merancang pembelajaran sehingga siswa dapat lebih mudah untuk memahami konsep-konsep translasi dan refleksi menggunakan suatu pendekatan pembelajaran matematika yang sesuai. Pendekatan saintifik merupakan salah satu alternatif pendekatan pembelajaran tesebut.

Pendekatan saintifik adalah suatu pendekatan berbasis proses keilmuan yang dimaksudkan untuk memberi pemahaman kepada siswa agar mengetahui, memahami, 
mempraktikkan apa yang sedang dipelajai secara ilmiah (Musfiqon \& Nurdyansyah, 2015). Selain itu, Beckmann (2010) menjelaskan bahwa pembelajaran saintifik dalam konteks bermakna dirancang untuk mengkontribusikan pemahaman matematika secara intuitif. Idenya adalah di satu sisi untuk menutup kesenjangan antara matematika formal dan pengetahuan autentik melalui penggunaan konteks serta metode yang diambil dari ilmu-ilmu alam. Pada sisi lain untuk memungkinkan siswa memperoleh kecakapan dari istilah matematika. Oleh karena itu, komunikasi matematika diperlukan agar siswa memdapatkan kecakapan tersebut.

Ontario (2010) menyatakan bahwa komunikasi matematika merupakan proses penting pelajaran matematika sebab melalui komunikasi siswa menanggapi, memperjelas dan memperluas ide dan pemahaman dari hubungan matematika dan argumentasi matematika. Adha \& Refianti (2018) mengungkapkan bahwa kemampuan komunikasi matematika siswa masih rendah yang terlihat dari kesulitan yang dialami siswa dalam mengaplikasikan matematika dalam situasi kehidupan nyata. Untuk itu, perlu komunikasi matematika siswa dalam pembelajaran agar siswa dapat memahami konsep belajar matematika.

Hasil penelitian Vebrian (2019) manyatakan desain pembelajaran dengan menggunakan konteks Bangka Belitung dapat mendukung KBKM siswa. Namun dalam penelitian desain pembelajaran difokuskan pada peran tesselation dan refleksi dalam mengembangkan komunikasi matematis siswa berdasarkan pendekatan saintifik

\section{METODE PENELITIAN}

Penelitian ini menggunakan metode design research type validation studies. Pada penelitian ini, terdapat suatu alur pembelajaran pada materi refleksi dan translasi menggunakan pendekatan saintifik berupa sederetan aktivitas siswa yakni dugaan-dugaan strategi dan pemikiran siswa yang dapat berubah dan berkembang selama proses pembelajaran.

\section{HASIL PENELITIAN}

Penelitian ini didesain dalam dua aktivitas yang terdiri dari saintifik pada materi translasi dan saintifik pada materi refleksi. Berikut ini deskripsi dari aktivitas-aktivitas tersebut.

\section{Aktivitas 1: Saintifik pada Materi Translasi}

Tujuan dari aktivitas ini adalah siswa dapat memahami dan menemukan konsep translasi melalui pembelajaran menggunakan pendekatan saintifik yang terdiri dari mengamati, menanya, menalar, mencoba, dan membentuk jejaring.

Pada kegiatan mengamati, siswa dapat memahami tentang translasi atau pergeseran dengan melakukan pengamatan terhadap objek berupa gambar pola dan siswa diminta untuk bisa menggeser pola tersebut.

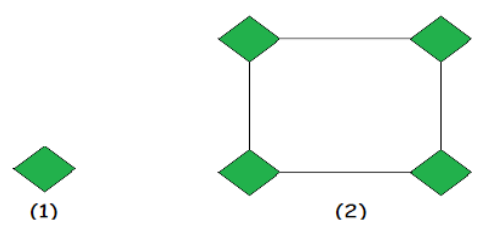

Gambar 1. Gambar Pola Mengenai Translasi 
Dalam aktivitas mengamati, terjadi komunikasi siswa dalam kelompok dan guru.

Fiedha : (Soal:Bagaimana cara menggeser pola segiempat pada gambar (1) agar menjadi seperti gambar (2)? "Ini bergeser ke bawah, terus ke kanan..." (Sambil menunjukkan gambar pola yang ada pada LAS)

Berliana : Maksudnya?"

Siswa : Fiedha, Nurlaili, Shakeilla sambil menunjuk gambar) "Ini nah, dari sini geser ke atas, ke kanan, ke bawah, ke kiri, itu maksudnya..."

Berliana : "Ooo..."

Guru : "Kalau dari bawah ke kanan, bagaimana?"

Siswa : "Ke kanan, ke atas, ke kiri, ke bawah...”.

Dari komunikasi di atas, dapat dilihat bahwa siswa dapat melakukan pergeseran sesuai pola yang mereka amati. Dengan adanya pemahaman tersebut, mereka dapat memberikan kesimpulan mengenai pergeseran.

Selanjutnya siswa melakukan aktivitas menanya dengan tujuan agar siswa dapat menentukan jarak dan arah pergerakan. Pada aktivitas ini, proses tanya jawab pun terjadi antara siswa dengan guru, yaitu sebagai berikut.

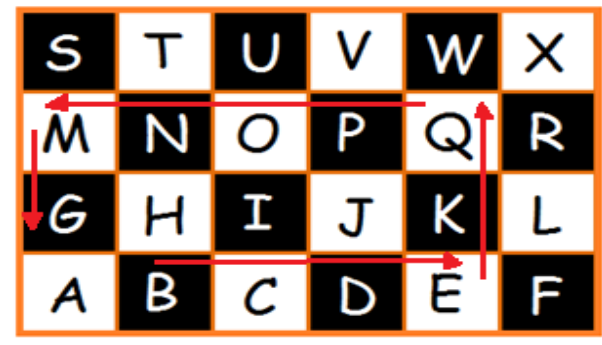

Gambar 2. Karpet Bermain Huruf
Khairani : "Jika Rangga diam di huruf $B$, berapa jaraknya? Berarti dari B ke D?".

Guru : "Nah... Rangga diam di B, arti diam? Coba kamu di sana! Kamu berdiri di sini saja, diam saja! Berapa jarak kamu?"

Khairani : "Tidak bergerak".

Guru : "Kamu tidak bergerakgerak, ada tidak jaraknya?"

Khairani : "Tidak ada".

Hal sama juga ditanyakan dengan siswa lain.

Hans : "Jika Rangga diam di huruf B, berapa jaraknya?"

Guru : "Sekarang saya tanya dengan kamu. Kalau kamu tidak pindah, kamu bayangkanlah. Kamu tidak pindah-pindah, di sinilah, berapa jaraknya?".

Hans : "Nol".

Dari proses tanya jawab yang terjadi, siswa dapat mengetahui dengan sendirinya bahwa jika sesuatu yang tidak bergerak, maka tidak akan ada jaraknya atau nol.

Aktivitas berikutnya adalah menalar. Aktivitas ini bertujuan agar siswa dapat menjelaskan pergeseran benda dalam koordinat kartesius. Komunikasi yang terjadi dalam proses bernalar adalah sebagai berikut.

Intan : "Kan nolnya itu B, coba tulis B! (Intan meminta Hans untuk memperjelas grafik yang telah dibuat agar lebih dimengerti) Nah, ke E kan katanya 1, 2, 3. Tiga langkah ke kanan. Nah, berati kan 3, E nya $(3,0)$ ") 
Hans : "Jadi, E(3,0)”.

Intan : "Ok. Terus Q, dari E kan dua langkah ke atas berarti $(3,2) Q$ nya. Nah, terus dari $Q$ ke M". (Sambil menghitung) " $1,2, \quad 3$, 4. Jadi, - 1".

Agel : "Tapi, kalau hitung dari $B ? "$

Intan : "Kalau dari B sama saja. Ini ke atas kan 2 terus ke kiri-1".

Agel : "Ooo... ya sudah lanjut...".

Hans : "Ini kan masih di 2, kan dari (3,2). Kalau di sini kan dapat $(2,-1)$ ".

Intan : "O ya, kan $(x, y)$, jadi ($1,2)$ ”.

Dalam percakapan di atas, dapat dilihat bahwa untuk merubah hurufhuruf menjadi titik-titik dalam koordinat kartesius mereka menggunakan grafik koordinat kartesius. Oleh karena itu, mereka dapat menentukan posisi huruf-huruf tersebut dalam koordinat kartesius sehingga menemukan titik-titiknya.

Setelah aktivitas menalar, dilanjutkan dengan aktivitas mencoba yang bertujuan agar siswa dapat menemukan konsep translasi. Pada aktivitas ini siswa menggunakan alat perga kertas berpetak. Hasilnya dapat dilihat pada gambar 3 .

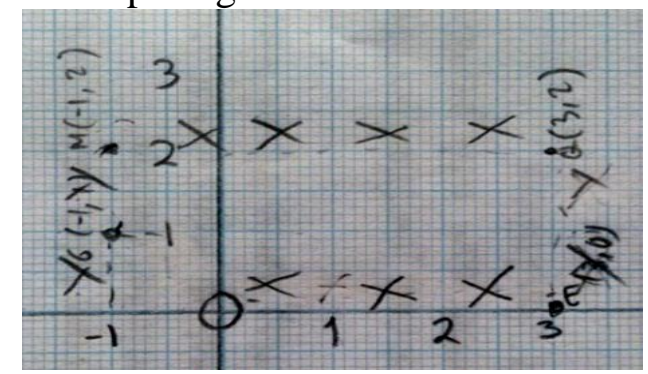

Gambar 3. Contoh Hasil Percobaan Siswa Menggunakan Kertas Berpetak dalam Mentranslasi Titik
Berdasarkan gambar 3, siswa membuat kembali titik-titik yang telah ditemukan pada aktivitas menalar. Dalam penggunaan kertas berpetak ini, mereka memberikan tanda $X$ untuk pergeseran pada sumbu $X$ dan tanda $Y$ untuk pergeseran pada sumbu $Y$ sesuai dengan petunjuk yang ada dalam LAS. Dari aktivitas tersebut, mereka dapat menemukan konsep translasi sehingga dari penggunaan kertas berpetak diperoleh hasil seperti gambar 4 .

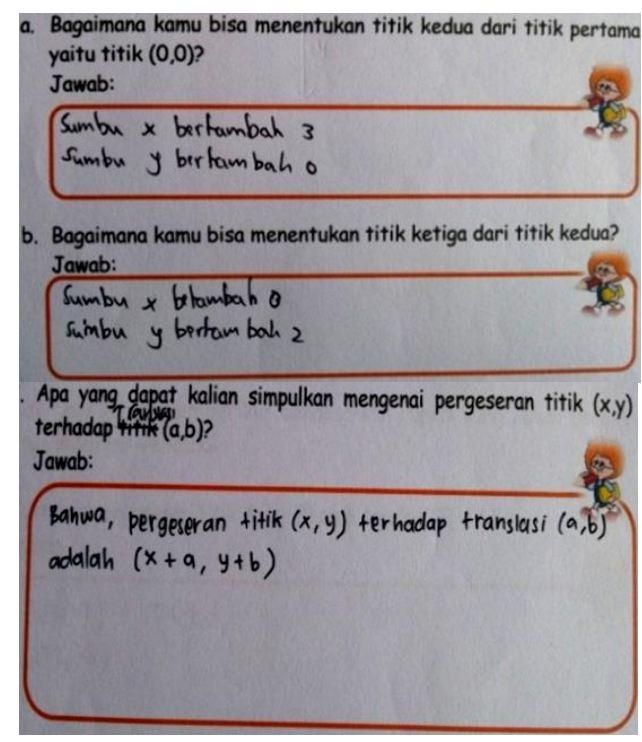

Gambar 4. Contoh Jawaban Siswa dalam Menentukan Konsep Translasi

Sesuai dengan gambar 4, siswa dapat menentukan bahwa dalam pergeseran titik itu akan selalu terjadi pertambahan pada sumbu $X$ dan sumbu $Y$. Dengan demikian, mereka memberikan kesimpulan di mana pergeseran titik $(x, y)$ terhadap translasi $\left(\begin{array}{l}a \\ b\end{array}\right)$ adalah $(x+a, y+b)$.

Setelah melakukan aktivitas mencoba, dilanjutkan dengan aktivitas membentuk jejaring yaitu siswa dapat menggunakan konsep translasi yang telah ditemukan dalam menyelesaikan masalah dan 
mempresentasikan hasil penyelesaian LAS ke depan kelas secara kelompok. Dalam hal ini, terjadi diskusi antar kelompok. Kelompok yang lain mengajukan pertanyaan kepada kelompok yang presentasi ke depan.

Sarah : "Maksud A' itu apa ya?"

Intan : " $A$ ' ini adalah hasil dari titik yang telah ditranslasikan"

Khairani : "Dari mana kalian bisa menemukan titik awal yaitu $(0,0) ? "$

Intan : "Titik $(0,0) \quad$ telah diketahui dari soal yaitu titik $B(0,0)$ "

Amien : "Dapat titik $(2,4)$ dari mana?"

Intan : " $3+(-1)$ menghasilkan 2 dan $(-2)+6$ menghasilkan 4"

Dhiya : "Mengapa titik $x$ lebih dulu disebutkan daripada titik $y$ ?"

Dimas : "Karena huruf $x$ lebih dulu daripada huruf y..."

Dari diskusi antar kelompok di atas, dapat diketahui bahwa siswa telah memiliki pemahaman mengenai translasi yang nampak pada saat siswa menjawab pertanyaanpertanyaan dari siswa lain. Hal ini menyebabkan siswa yang bertanya pun menjadi mengerti.

Setelah melalui 5 aktivitas yaitu mengamati, menanya, menalar, mencoba, dan membentuk jejaring, siswa memiliki kreaktivitas yaitu menciptakan sesuatu. Dalam hal ini yang diciptakan adalah membuat gambar pola yang dapat dilihat pada gambar 5.

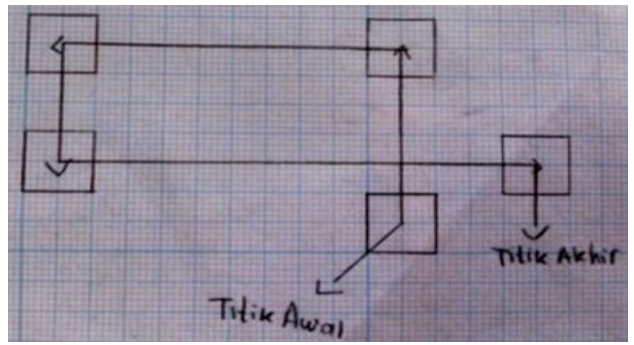

Gambar 5. Contoh Hasil Pekerjaan Siswa dalam Membuat Gambar Menggunakan Translasi

Berdasarkan aktivitas-aktivitas yang telah dilakukan dapat disimpulkan bahwa siswa mampu menemukan konsep translasi. Oleh karena itu, siswa memiliki pemahaman dan pengetahuan mengenai materi translasi.

\section{Aktivitas 2: Saintifik pada Materi Refleksi}

Siswa dapat memahami dan menemukan konsep refleksi melalui aktivitas-aktivitas yaitu mengamati, menanya, menalar, mencoba, dan membentuk jejaring.

Pada aktivitas mengamati, siswa dalam kelompoknya mengamati gambar yang ada pada LAS sehingga dari pengamatan tersebut, siswa mendapatkan pemahaman dalam menggambar pola menggunakan pencerminan yang dapat dilihat pada gambar 6.

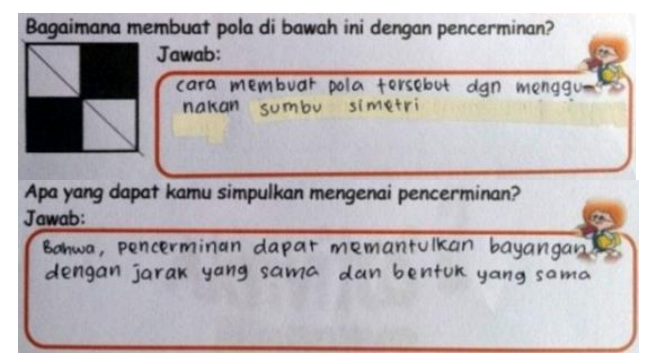

Gambar 6. Contoh Jawaban Siswa dalam Membuat Mengenai Pencerminan

Berdasarkan gambar 6, siswa melakukan pengamatan terhadap 
gambar sehingga dari pemahaman gambar tersebut, mereka dapat mengetahui bahwa dalam menggambar pola sesuai dengan pencerminan adalah menggunakan sumbu simetri. Oleh karena itu, siswa mempunyai pemahaman terhadap pencerminan.

Setelah melakukan aktivitas mengamati, siswa melakukan aktivitas menanya. Dalam hal ini siswa bertanya kepada guru.

Amien : "Soal no. 2 ini, sudutnya yang antara objek dengan bayangan atau objek dengan cermin? (Soal: Apakah garis tersebut tegak lurus dengan cermin? Jika ya, berapa besar sudutnya?)

Guru : "Sudut antara objek dengan cermin atau bayangan dengan cermin".

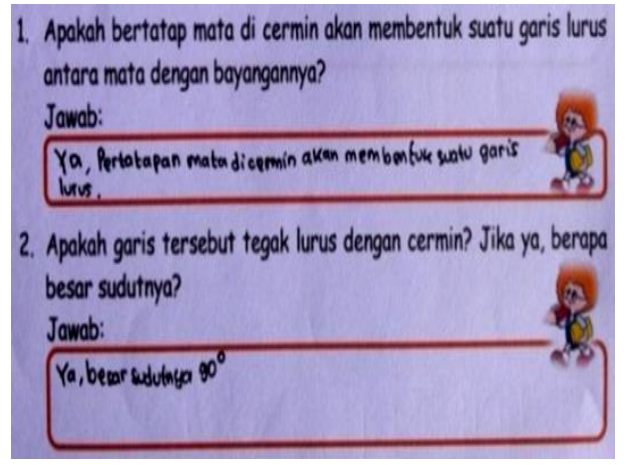

Gambar 7. Contoh Jawaban Siswa Pada Aktivitas Menanya Mengenai Refleksi

Berdasarkan tanya jawab yang telah terjadi dan dari gambar 7 , siswa dapat menentukan bahwa sudut yang dibentuk dalam pencerminan adalah $90^{\circ}$.

Aktivitas selanjutnya adalah aktivitas menalar, di mana siswa berpikir bagaimana cara menyelesaikan masalah dalam LAS. Pada aktivitas ini terjadi komunikasi antara siswa dalam kelompoknya dan juga guru.

Amalia : "Jika suatu titik terletak pada cermin, maka di manakah bayangannya?

Elva : "Tepat di depannya dan jaraknya sama..."

Kohar : "Tepat di depan objek itu dan jaraknya sama"

Elva : "Jarak, bentuk, sama... Arahnya pun juga sama karena titik..."

Amalia : "Arahnya beda.

Berapakah jarak antara titik itu dengan bayangannya?Ya... tergantung".

Kohar : "Sama seperti jarak objek itu".

Amalia : "Jaraknya sama".

Elva : "Jaraknya sesuai titik tersebut".

Siswa bertanya dengan guru:

Dhiya : "Jika suatu titik terletak pada cermin, maka di manakah bayangannya?"

Guru : "Jika suatu titik terletak pada cermin, di mana bayangannya?" (guru mengambil buku). "Jika titik terletak di sini (menganggap buku sebagai cermin), di mana bayangannya?

Dhiya : "Menempel... berarti di titik itulah..."

Guru : "Nah... Kalau bayangan titik pada cermin, ada atau tidak jaraknya?"

Siswa : "Tidak ada" (menjawab serentak dalam kelompok)

Guru : "Kalau tidak ada...?

Siswa : "Nol kan menempel"

Berdasarkan percakapan di atas, siswa dapat lebih mudah menjawab bahwa jika suatu titik terletak pada cermin, maka jarak bayangannya ke cermin adalah nol karena posisi titik dengan bayangannya akan menempel. 
Setelah melakukan aktivitas menalar dilanjutkan dengan aktivitas mencoba. Siswa melakukan percobaan menggunakan alat peraga kertas berpetak untuk menemukan konsep pencerminan. Dalam hal ini, siswa mencerminkan dua titik terhadap sumbu $X$, sumbu $Y$, dan titik $(0,0)$.

Hasil-hasil yang diperoleh dari pencerminan tersebut, dijadikan petunjuk dalam membuat kesimpulan untuk menentukan konsep refleksi. Contoh jawaban yang diperolah siswa dalam aktivitas mencoba ini dapat dilihat pada gambar 8 dibawah ini.

Berdasarkan gambar 8, siswa melakukan percobaan menggunakan alat peraga untuk mencerminkan 2 titik yaitu $(3,5)$ dan $(4,1)$ terhadap sumbu $X$, sumbu $Y$, dan titik $(0,0)$. Dari percobaan tersebut siswa menemukan konsep pencerminan terhadap sumbu $X$ yaitu $(x,-y)$, pencerminan terhadap sumbu $Y$ yaitu $(-x, y)$, dan pencerminan terhadap titik $(0,0)$ yaitu $(-x,-y)$.

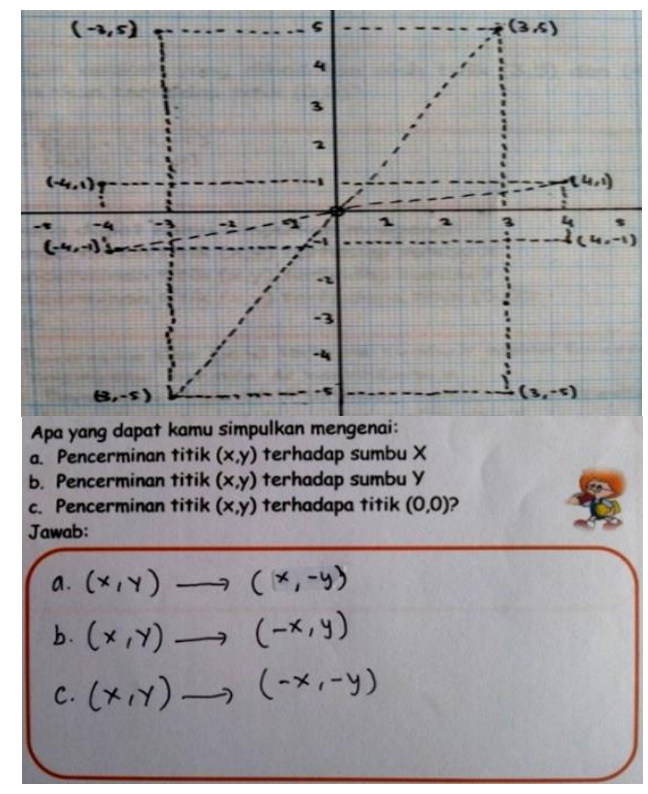

Gambar 8. Contoh Jawaban Siswa dalam Menentukan Konsep Refleksi
Selanjutnya setelah melakukan aktivitas mencoba, siswa melakukan aktivitas membentuk jejaring dengan mempresentasikan hasil penyelesaian dalam LAS. Dalam hal ini terjadilah diskusi antar kelompok dan timbullah proses tanya jawab antar kelompok.

Khairani : "Pada soal nomor 2 aktivitas 2, apakah garis itu tegak lurus dengan cermin, kalian menjawab 'ya'. Jika ya berapa besar sudutnya, kalian menjawab ' $90^{\circ}$ '. Nah, mengapa besar sudutnya $90^{\circ}$ sedangkan besar sudut garis tegak lurus sebenarnya adalah $180^{\circ}$ ?"

Berliana : "Menurut kami, ini kan tegak lurus. Nah ini ada garis lurus dibagi dua. Jadi, yang ini $90^{\circ}$ dan sebelah sini $90^{\circ}$. Kalau digabungkan menjadi $180^{\circ}$ ".

Khairani : "Bukannya kalau garis tegak lurus itu walau misalnya dibagi dua tetap $180^{\circ}$ karena garis tegak lurus.... Kalau $90^{\circ}$ kan siku-siku, itu 90. Kalau garis tegak lurus $180^{\circ}$ mau besar, mau panjang, mau pendek tetap $180^{\circ} . "$

Berliana : "Bukannya ini kan satu garis..."

Khairani : "Ya, satu garis. Garisnya kan satu garis."

Berliana : "Jadi, garis ini hanya satu garis."

Khairani : "Jadi, kalau garis tegak lurus $180^{\circ}$. Nah, dibagi dua menjadi $90^{\circ}$. Kalau $90^{\circ}$ itu artinya siku-siku.

Kemudian guru menjelaskan kembali pertanyaan yang diajukan oleh Khairani dengan meminta 
kelompok yang maju untuk menunjukkan sudut tegak lurus pada gambar yang besarnya $90^{\circ}$ dan juga Khairani yang menyatakan kalau sudut tegak lurus itu adalah $180^{\circ}$. Setelah mereka menunjukkan masingmasing pendapatnya pada gambar, guru memberikan pertanyaanpertanyaan kepada mereka sehingga mereka menyadari dan memahami kalau besar sudut tegak lurus adalah $90^{\circ}$.

Dari aktivitas-aktivitas yang dilakukan, siswa bisa mencipta yaitu dengan membuat gambar menggunakan refleksi. Gambar yang dibuat siswa dapat dilihat pada gambar 9 .

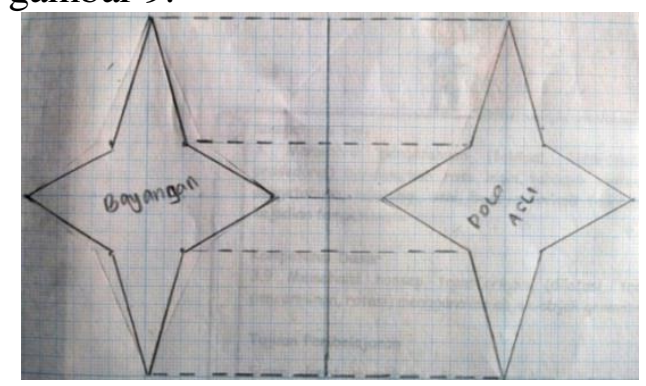

Gambar 9. Contoh Gambar yang dibuat Oleh Siswa Menggunakan Refleksi

Berdasarkan aktivitas-aktivitas yang telah dilalui, dapat diketahui bahwa siswa telah memiliki pemahaman dalam mempelajari refleksi. Oleh karena itu, siswa pun telah mempunyai pengetahuan yang baik mengenai refleksi yang dapat dilihat dari gambar yang mereka buat sendiri.

\section{PEMBAHASAN}

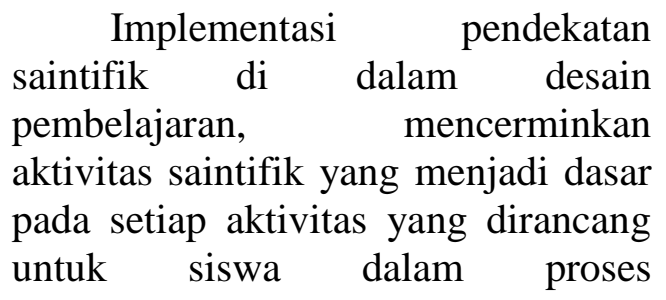

pembelajaran pada materi translasi dan refleksi. Desain aktivitas saintifik tersebut terdiri dari 5 aktivitas yang dikemukan oleh Kemdikbud (2013) yaitu mengamati, menanya, menalar, mencoba, dan membentuk jejaring.

Langkah yang pertama yaitu mengamati dengan menggunakan objek berupa gambar yang berkaitan dengan kehidupan sehari-hari berupa pola atau peristiwa. Aktivitas ini bertujuan agar siswa dapat menemukan pemahaman awal yang bisa berupa sifat-sifat dari translasi dan refleksi. Penggunakan gambar pola sesuai dengan penelitian Fonseca \& Vale (2009) yang mengatakan bahwa pola (termasuk pola dalam tesselation) banyak memberikan peluang dalam belajar konsep matematika dan pengembangan proses matematika yang diantaranya seperti komunikasi matematika terutama dalam mempelajari translasi dan refleksi.

Pada aktivitas 1, pemahaman siswa mengenai translasi dengan mengamati gambar pola. Dari pengamatan gambar pola tersebut, siswa dapat membuat kesimpulan mengenai translasi. Dalam pengamatan ini, siswa akan menentukan bagaimana cara membuat pola yang tertera pada LAS. Dengan mengetahui cara membuat pola itu, maka siswa dapat membuat kesimpulan tentang translasi. Selanjutnya di aktivitas 2, siswa mengamati gambar mengenai suatu peristiwa. Dari gambar tersebut, siswa dapat menemukan sifat-sifat refleksi. Dengan pemahaman tersebut, siswa juga dapat membuat gambar pola seperti pada LAS dengan menggunakan pencerminan.

Langkah kedua yaitu menanya. Kegiatan menanya ini digunakan agar siswa memberikan pertanyaan- 
pertanyaan dalam memahami permasalahan dalam pembelajaran. Menurut Rosalin (2008), bertanya dapat membangkitkan respon siswa. Dari proses bertanya inilah, siswa akan memperoleh pemahaman dan pengetahuan mengenai translasi dan refleksi. Pada aktivitas 1, siswa diberikan permasalahan mengenai pergerakan dalam karpet huruf untuk menemukan huruf sesuai yang ada pada LAS. Dari permasalahan itu timbullah pertanyaan siswa yaitu "jika diam, berapa jaraknya?". Di aktivitas 2, pertanyaan yang muncul adalah "apakah sudut yang dibentuk adalah antara objek dengan cermin atau bayangan dengan cermin?".

Langkah ketiga yaitu menalar. Kegiatan ini bertujuan agar siswa dapat menggunakan proses berpikirnya dalam menyelesaikan suatu permasalahan. Pada aktivitas 1, siswa dapat menentukan pergeseranpergeseran dalam koordinat kartesius dengan mengubah huruf-huruf dalam karpet huruf menjadi angka-angka dan menjadi titik-titik dalam koordinat kartesius. Di aktivitas 2, siswa dapat menentukan jarak antara titik yang terletak pada cermin dengan bayangannya dengan cara membayangkannya dengan memperagakan dengan suatu benda. Langkah ke empat yaitu mencoba. Dengan menggunakan alat perga kertas berpetak, siswa dapat menentukan konsep translasi dan refleksi.

Langkah ke lima yaitu membentuk jejaring. Siswa dapat menyelesaikan soal yang berkaitan dengan translasi dan refleksi serta mengkomunikasikan hasil dari setiap aktivitas ke depan kelas. Dari kegiatan ini, siswa dapat memperoleh pemahaman tambahan mengenai translasi dan refleksi setelah terjadi diskusi antar kelompok. Melalui langkah-langkah yang telah dilakukan dari mengamati sampai membentuk jejaring akan menimbulkan suatu kegiatan mencipta. Di sini, siswa dapat membuat gambar menggunakan translasi dan refleksi.

Secara keseluruhan dapat dikatakan bahwa aktivitas belajar yang dilaksanakan dalam penelitian ini telah berdasarkan langkah-langkah pendekatan saintifik. Dari lima langkah pendekatan saintifik tersebut, yang paling menonjol adalah membentuk jejaring karena langkah ini selalu ada pada setiap langkah yang lain. Hal ini menyebabkan bahwa pembelajaran dengan menggunakan pendekatan saintifik dapat mengembangkan kemampuan komunikasi matematika siswa.

\section{SIMPULAN}

Pembelajaran menggunakan tessellation dengan pendekatan saintifik efektif membantu siswa memahami konsep-konsep translasi dan refleksi, melalui kegiatan seperti mengamati, menanya, menalar, mencoba, dan membentuk jejaring

\section{DAFTAR PUSTAKA}

Adha, I \& Refianti, R. (2018). Missauri Mathematics Project Berbasis Soal Open Ended Terhadap Kemampuan Komunikasi Matematika. Judika Education, 1(2), 135 143.

Beckmann, A. (2010). Learning Mathematic Through Scientific Contents and Methods. Germany: University of Education Schwabisch Gmund.

Deger, K., O \& Deger, A., H. (2012). An Apllication of Mathematics Tessellation Method in Inteior Designing. Procedia: Sosial 
and Behavioral Sciences, 51, $249-256$.

Fonseca, L. \& Vale, I. (2009). Challenging Pattern Tasks With Geometric Transformations in Elementary Teachers Training: Tessellations, Polygons Patterns and Kaleidoscopes. Proceedings CIEAEM 61-Montreal, Quebec, Canada. Quaderni di Ricerca in Didattica (Matematica), Supplemento n.2, 263-271.

Guven, B. (2012). Using Dynamic Geometry Software to Improve Eight Grade Students' Understanding of Transformation Geometry. Australasian Journal of Educational Tecchnology, 28(2), 364-382.

Hollebrands, K. F. (2003). High school students' understanding of geometric transformations in the context of a technological environment. Journal of Mathematical Behavior, 22: 5572.

Kemdikbud. (2013). Diklat Guru dalam Rangka Implementasi Kurikulum 2013. Jakarta: Kemdikbud.

Kershaw, J. (2014). CK-12 Middle School Math Concept Grade 6. Amerika Serikat: Flexbook.

Musfiqon, HM \& Nurdyansyah. (2015). Pendekatan

Pembelajaran Saintifik. Nizamia Learning Center: Sidoarjo.

Ontario Ministry of Education. (2010). Communication in the Mathematic Classroom. Toronto: On Queen's Printer for Ontario.

Rosalin, E. (2008). Gagasan Merancang Pembelajaran Kontekstual. Bandung: PT Karsa Mandiri Persada.
Tunnisa, M., Rizal, M., \& Karniman, T.,S. (2018). Penerapan Pendekatan Pendidikan Matematika Realistik pada Materi Transformasi untuk Meningkatkan Hasil Belajar Siswa di Kelas IXA SMPN 1 Tanantovea. Jurnal Elektronik Pendidikan Matematika Tadulako, 5(4), 401 - 413.

Vebrian, R., \& Putra, Y. (2019). Desain Pembelajaran Penjumlahan dan Pengurangan Bilangan Menggunakan Konteks Bangka Belitung untuk Mendukung KBKM Siswa. Jurnal Pendidikan Matematika (JUDIKA EDUCATION), 2(1), 11-24.

https://doi.org/https://doi.org/10 .31539/judika.v2i1.718 